Pesq. Vet. Bras. 29(4):353-357, abril 2009

\title{
Expression and distribution of connexin 32 in rat liver with experimentally induced fibrosis ${ }^{1}$
}

\author{
Alexandro dos S. Rodrigues ${ }^{2^{*}}$, Maria L. Zaidan Dagli ${ }^{3}$, José L. Avanzo ${ }^{3}$, Helder \\ P. de Moraes $^{2}$, Ivone I. Mackowiak ${ }^{3}$ and Francisco J. Hernandez-Blazquez ${ }^{2}$
}

\begin{abstract}
Santos-Rodrigues A., Dagli M.L.Z., Avanzo J.L., Moraes H.P., Mackowiak I.I. \& Hernandez-Blazquez F.J. 2009. Expression and distribution of connexin 32 in rat liver with experimentally induced fibrosis. Pesquisa Veterinária Brasileira 29(4):353357. Departamento de Cirurgia, Setor de Anatomia, Faculdade de Medicina Veterinária e Zootecnia, Universidade de São Paulo, Av. Prof. Dr. Orlando Marques de Paiva 87, São Paulo, SP 05508-270, Brazil. E-mail: alexsantos@usp.br

The connexin $32(\mathrm{C} \times 32)$ is a protein that forms the channels that promote the gap junction intercellular communication (GJIC) in the liver, allowing the diffusion of small molecules through cytosol from cell-to-cell. Hepatic fibrosis is characterized by a disruption of normal tissue architeture by cellular lesions, and may alter the GJIC. This work aimed to study the expression and distribution of $\mathrm{Cx} 32$ in liver fibrosis induced by the oral administration of dimethylnitrosamine in female Wistar rats. The necropsy of the rats was carried out after five weeks of drug administration. They presented a hepatic fibrosis state. Sections from livers with fibrosis and from control livers were submitted to immunohistochemical, Real Time-PCR and Western-Blot analysis to Cx32. In fibrotic livers the Cxs were diffusely scattered in the cytoplasm, contrasting with the control livers, where the $\mathrm{C} \times 32$ formed junction plaques at the cell membrane. Also it was found a decrease in the gene expression of $\mathrm{Cx} 32$ without reduction in the protein quantity when compared with controls. These results suggest that there the mechanism of intercellular communication between hepatocytes was reduced by the fibrotic process, which may predispose to the occurrence of a neoplastic process, taken in account that connexins are considered tumor suppressing genes.
\end{abstract}

INDEX TERMS: Dimethylnitrosamine, fibrosis, liver, Cx32, gap junctions.

\begin{abstract}
RESUMO.- [Expressão e distribuição da conexina 32 em fígados de ratos com fibrose induzida experimentalmente.] A conexina 32 (Cx32) é uma proteína que constitui os canais que promovem as comunicações intercelulares via junções comunicantes (CIJC) no fígado, permitindo difusão de pequenas moléculas citoplasmáticas de uma célula à outra. A fibrose hepática caracteriza-se pela alteração da arquitetura normal do fígado e podem alterar
\end{abstract}

\footnotetext{
${ }^{1}$ Received on July 24, 2008.

Accepted for publication on March 11, 2009.

2 Departamento de Cirurgia, Setor de Anatomia, Faculdade de Medicina Veterinária e Zootecnia, Universidade de São Paulo, Av. Prof. Dr. Orlando Marques de Paiva 87, São Paulo, SP 05508-270, Brazil. *Corresponding author: alexsantos@usp.br

${ }^{3}$ Departamento de Patologia, Faculdade de Medicina Veterinária e Zootecnia, USP, São Paulo, SP.
}

as CIJCs. O objetivo deste trabalho foi estudar a expressão e distribuição de Cx32 na fibrose hepática. O objetivo do presente trabalho foi estudar a expressão e distribuição da Cx32 em fígados com fibrose induzida pela administração oral de dimetilnitrosamina em fêmeas de ratos Wistar. A necropsia foi realizada após cinco semanas da última administração da droga e observou-se um quadro de fibrose hepática. Amostras dos fígados com fibrose e de animais controle foram submetidas à análise imunoistoquímica, por Real Time-PCR e por Western-Blot verificando-se a presença de Cx32 difusa e dispersa no citoplasma dos fígados com fibrose. No grupo controle a Cx32 localizou-se na membrana citoplasmática com a formação de placas juncionais. O fígado com fibrose também revelou diminuição da expressão gênica de Cx32, embora sem a redução da quantidade do produto protéico, quando comparado ao grupo controle. Estes resultados suge- 
rem que o mecanismo de comunicação intercelular entre os hepatócitos reduziu-se durante o processo fibrótico, o que pode predispor a ocorrência de processos neoplásicos, uma vez que as conexinas são consideradas genes supressores de tumores.

TERMOS DE INDEXAÇÃO: Dimetilnitrosamina, fibrose, fígado, Cx32, junção comunicante.

\section{INTRODUCTION}

Liver fibrosis occurs as a result of toxic lesions and inflammation of the liver, and may have several causes. The difference between liver fibrosis and other histopathological conditions of the liver is the fact that fibrosis is usually a progressive lesion that changes the hepatic architecture and function. This pathological process is called cirrhosis (Johnson 2000, Crawford 2005), which may favor more severe morphological changes, such as a cancer. In dogs, fibrosis is a consequence of chonic hepatitis and often progresses to cirrhosis (Watson 2004).

Hepatocytes, like any cell of multicellular organisms, need to be in contact with other cells. Among the several cell-tocell contact points, gap junctions are structures that allow cytosolic communication between adjacent cells and direct exchanging of small molecules (Saez et al. 1989). Gap junctions which play a very important role in maintaining tissue homeostasis and control of cell differentiation and proliferation (Yamasaki 1991). They are formed by transmembrane channels called connexons that are composed by protein subunits called connexins (Cxs). Hepatocytes gap junctions are constituted by two predominant types of connexins: Cx32 and Cs26 (Zhang \& Nicholson 1989). Gap junctions allow ions and small molecules that regulate cell proliferation to enter the cytoplasm, thus being directly involved in homeostasis control, preventing a neoplastic alteration (Yamasaki 1991). This has been confirmed in seven types of human hepatocellular carcinomas, where considerable less, quantity of connexins per square millimeter is found when compared with non-carcinomatous cirrhotic tissues (Yamaoka 1995). Connexin 32 expression seems to be importante in liver disease progression to spontaneous or chemichally induced liver tumors (Temme et al. 1997, Moennikes et al. 1999).

Fibrosis is a state that precedes cirrhosis (Friedman 1993, Pines et al. 1997, Paradis et al. 1999, Yasuda et al. 1999, Lee et al. 2004, Crawford 2005) and is secondary to severe hepatic lesions and may significantly contribute to the disease and death (Cheville 1999). Cxs32 show an important correlation with cirrhosis and tumors. Here we studied the expression and location of connexin 32 (Cx32) during chemically induced fibrosis to verify how these characteristics are affected in the fibrosis process.

\section{MATERIALS AND METHODS}

\section{Animals and experimental design}

Thirty-month-old female Wistar rats weighing $220 \pm 10$ g were employed in this study. They were fed with standard rat diet and water ad libitum and housed in cages with controlled temperature and humidity. Rats were provided by the animal facility of the Department of Pathology of the School of Veterinary Medicine, University of São Paulo. All rats received human care according to the criteria outlined in the 'Guide for the Care and Use of Laboratory Animals' and the experimental procedure was approved by the institutional Bioethics Committee (protocol number 1046/2007). Fibrosis was induced by gastric gavage with an aqueous solution of dimethylnitrosamine (DMN, SigmaAldrich, St Louis, Missouri, USA) during five weeks, twice a week $(10 \mathrm{mg} / \mathrm{kg})$, followed by a resting period of four weeks. Rats were identified and distributed into 2 groups of 15 animals each and classified as group 1D and group 2C. Group 1D comprised animals that were given dimethylnitrosamine (DMN). After this period, the animals were observed for five weeks and than were euthanized. Animals of group $2 \mathrm{C}$ (control group), which did not receive dimethylnitrosamine (DMN), were euthanized together with group 1D animals.

\section{Histology and immunohistochemistry procedure}

Fragments from each liver were fixed in Bouin fixative for 12 hours, embedded in paraffin wax, and $5 \mu \mathrm{m}$ tissue sections were stained with hematoxylin-eosin, picrosirius-hematoxylin and picrosirius alone for a histopathologic examination by a veterinary pathologist. Liver samples were stored in liquid nitrogen for Real Time-PCR (Real Time Polymerase Chain Reaction), WesternBlot and immunohistochemistry analyses. Frozen tissue samples were cut in cryostat $(7 \mathrm{~mm})$, ixed in metacarn for 10 minutes and used for identification of the $\mathrm{C} \times 32$. The sections were incubated overnight with rabbit anti-connexin 32 polyclonal antibodies $\left(\right.$ Zymed $^{\circledR}$, South San Francisco, USA) diluted 1:500 in PBS (Phosphate Buffer Solution) followed by biotinylated goat anti-rabbit secondary antibody (Dako ${ }^{\circledR}$, Carpinteria, USA) diluted 1:300 in PBS for one hour. In the next step, the slides were incubated by 30 minutes with 1:100 streptavidin-peroxidase and visualized by. tyramide-fluorescein from TSA Fluorescence Kit visualization system (PerkinElmer Life Science Inc $\circledast$, Boston USA). Nuclei were counterstained with propidium iodide (Sigma ${ }^{\circledR}$, St Louis, USA) at a concentration of $10 \mathrm{mg} / \mathrm{ml}$. The slides were mounted with Prolong Gold Antifade Reagent (Invitrogen, Carlsbad USA) permanent mounting media.

\section{Western-blot}

After cell lysis of the hepatic tissue $(40 \mathrm{mg}), 150 \mathrm{mg}$ of protein lysate to which bromophenol blue was added were subjected to sodium dodecyl sulfate polyacrylamide gel electrophoresis on $10 \%$ acrylamide gels with $10 \mathrm{ml}$ of Kaleidoscope Prestained Standard (Bio-Rad Labs ${ }^{\circledR}$, California, USA) as molecular weight marker..The proteins were transferred to a PDVF (Polyvinylidene Fluoride) $8.0 \times 5.0 \mathrm{~cm}^{2}$ membrane (Trans-Blot SD cell; Bio-Rad Labs $^{\circledR}$, California, USA) and incubated for 1 hour in $5 \%$ skim milk in 7.2 M PBS followed overnight incubation with rabbit anti-Cx32 polyclonal antibody (Zymed) diluted 1:100 in PBS. The blot was washed in PBS and incubated for 1 hour with goat anti-rabbit peroxidase-conjugated antibody (Zymed) diluted 1:1000 in PBS. The bands were visualized with a solution containing diaminobenzidine (DAB)-nickel in PBS to which 20 $\mu \mathrm{l}$ of hydrogen peroxide at $30 \%$ were added.

\section{mRNA quantification by RT-PCR}

Total RNA was extracted using Trizol Reagent (Invitrogen Life Technologies, Carlsbad, CA, USA) according to manufacturer's instructions. RNA integrity check was run in $1.5 \%$ 
agarose gel. RNA quantification was carried out by the Biophotometer (EppendorfOे, USA). Total RNA was treated with DNAse I (Invitrogen) in order to remove all remaining DNA. After cDNA construction, quantitative real-time PCR was carried ou with the ABI PRISM 7000 Sequence Detection System (Applied Biosystem, Foster City, California) using TaqMan Universal Master Mix (Applied Biosystems) for detection of Cx32 and betaactin (housekeeping gene) gene expression.

The primers and probes specific for $\mathrm{C} \times 32$ and beta-actin were selected with the Primer Express software programs (Applied Biosystems). The Cx32 forward primer 5'GGGTGGCCTCAAGGATAG-3' and the reverse primer 5'ATGAACTGGACAGGTCTATACACC-3' were chosen to amplify a 69-bp fragment. The internal Cx32 TaqMan probe used was FAM-5'- CTCCCCAGGTGTGAATG -3'NFQ. The beta-actin primers, 5'-AGATTACTGCCCTGGCTCCTA-3' (forward primer, $82 \mathrm{bp}$ ), the reverse primer 5'-CAAGTACTCTGTGTGGATTGGTGG-3' and the TaqMan probe (VIC-5'ACCATGAAGATCAAGATCAT-3'-MGBNFQ were used as housekeeping control. The internal $\mathrm{C} \times 32$ and beta-actin TaqMan probes were designed following the manufacturer's general rules. The analysis of relative gene expression was performed according to the $2^{\text {-DDCT }}$ method (Livak \& Schmittgen 2001).

\section{RESULTS}

Liver fibrosis was found in all animals treated with DMN, with the presence of the following lesions: regenerative nodules, fibrosis and fibrotic bridges, inflammatory infiltrate with oval cells proliferation, bile ducts proliferation and megalocytosis. Immunohistochemical analysis showed that the Cxs32 was located at the hepatocyte cell membrane in rats of the control group (group 2C), forming fluorescent spots that characterize the gap junctions. The cytoplasm also showed light and difuse staining (Fig.1a). In DMN-treated animals the Cx32 proteins, the Cxs32 was mainly concentrated in the hepatocyte cytoplasm, around the nuclei (Fig.1b).

The mRNA Cx32 level in liver with fibrosis was $40 \%$ lower than in the liver of the rats from the control group when the data was normalized with the level of mRNA expression of the constitutive gene beta-actin Amplification peak means were 0.66 for animals treated and 1.16 for

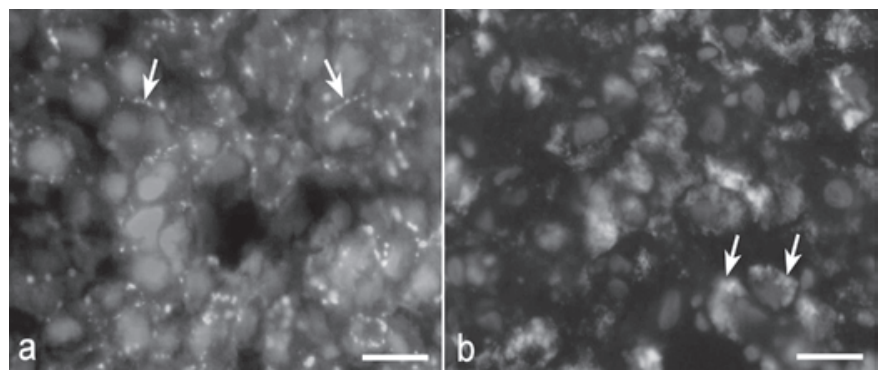

Fig.1. Photomicrographs of histological sections of the liver of animals from (a) Group 2C (control group), showing positive reaction for $\mathrm{Cx} 32$ (arrows) in cell membranes of hepatocytes, and (b) the $\mathrm{C} \times 32$ forming intracytoplasm aggregates (arrows) in hepatocytes of fibrotic liver. The nuclei were stained light grey (using propidium iodate) for background contrast. Bar $=50 \mu \mathrm{m}$.
Table 1. Levels of normalized connexin 32 mRNA in livers of rats treated or not treated with DMN measured by quantitative Real Time-PCR

\begin{tabular}{ccc}
\hline $\begin{array}{c}\text { Groups } \\
(\mathrm{N}=6)\end{array}$ & $\begin{array}{c}\text { Difference in cycles between } \\
\text { Cx32 and B-actin "CT }\end{array}$ & $\begin{array}{c}\text { Normalized Cx32 } \\
\text { amount 2-"'"CT }\end{array}$ \\
\hline $\begin{array}{c}\text { Treated } \\
\text { Not treated }\end{array}$ & $9.66 \pm 0.9$ & $0.66 \pm 0.3^{*}$ \\
\hline
\end{tabular}

The means in the same column followed by asterisk $\left({ }^{*}\right)$ were significantly different under Student $t$ test $(p<0.05)$.

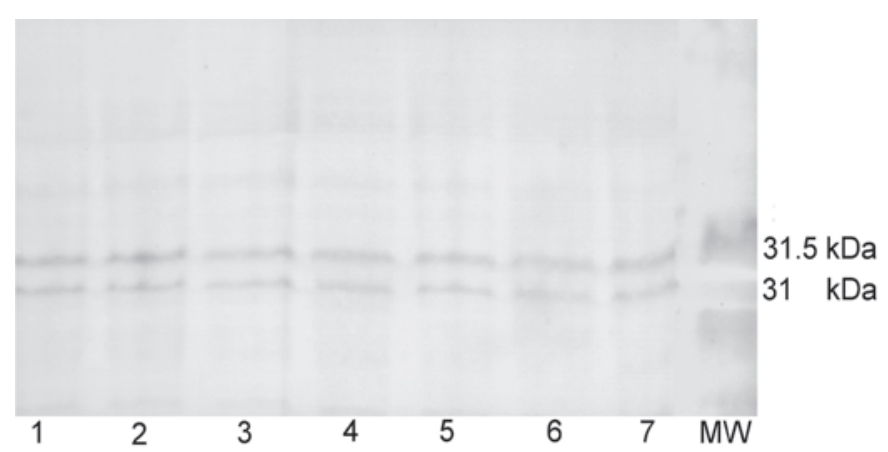

Fig.2. Western blot of hepatic tissue for $\mathrm{Cx} 32$ of the rats treated and not treated with DMN. 1 to 3: Control rats not treated with DMN; 4 to 7: Rats treated with DMN and that developed fibrosis; MW: Molecular weight marker. The weight of the molecular marker is indicated at the right of the figure.

non-treated animals (Table 1). The analysis resulting from Western-blot method showed that the Cxs32 in liver tissues did not present any differences in terms of size of protein products between the animals treated with $\mathrm{DMN}$ and the ones that were not treated (Fig.2).

\section{DISCUSSION}

We used DMN as fibrosis-inducing drug because it is a potent hepatotoxic agent (Barnes \& Magee 1954), because of its total metabolization in the liver and because it can reproduce fibrosis in a most accurate way in animals and humans (Magee 1956 1958). The immunohistochemical technique showed that $\mathrm{C} \times 32$ was located in the cell membrane forming junction plaques in control animals, a fact that was expected, since Cxs are the proteins responsible for forming gap junctions between neighboring cells. In contrast, after treatment with DMN, the Cxs32 appeared rather diffusely scattered in the cytoplasm. Recently, in vitro studies verified that Cxs32 can be expressed without forming gap junctions, being accumulated in the cytoplasm, if their intracellular transport mechanism is deficient (Hernandez-Blázquez et al. 2001) or in the absence of E-cadherin (Yano et al. 2001). That could explain the atypical plaques and the increase of mRNA without increase of gap junctions described by Nakata et al. (1996). The reason for this difference in location is not clear, but it may be due to the fact that in the liver, post-lesion regenerative processes multiply and decrease intercellular communication mediated by gap junctions. 
With regard to the results obtained from molecular analyses, we observed a $40 \%$ decrease in gene expression for Cx32 in animals treated with DMN using Real Time $\mathrm{PCR}$ technique. This decrease in gene expression of $\mathrm{C} \times 32$ may be due to up-down regulation mechanisms or negative regulation, which is caused by the organism itself in an attempt of recover homeostasis.

In order to discover if the gene expression for $\mathrm{Cx} 32$ was accompanied by decrease in the quantity of protein present in cells, the western-blot technique was used. However, there were no differences between animals treated with DMN (rats with liver fibrosis) and animals not treated in what relates to the amount of the protein product. This may indicate that the translation system is in principle intact, and that the treatment did not suffice for promoting significant changes. With respect to the quantity of $\mathrm{C} \times 32$ available for the cell, no reduction in the quantity of protein product in rats with fibrosis was observed, which indicates that reduction in the quantity of Cx32 mRNA in liver fibrosis is not accompanied by reduction in protein product quantity. A hypothesis to explain this fact may come from the finding that in control animals $\mathrm{Cxs}$ were in the membrane, whereas in treated animals they were in the cytoplasm. The Cxs present in cytoplasm that did not form gap junctions have a prolonged half-life, as demonstrated by HernandezBlazquez et al. (2001) in cells treated with cycloheximide, a protein synthesis inhibitor. After 48 hours of protein synthesis blockade, Cxs of the types 43 and 26 were still present in the cytoplasm and were able to form functional channels when stimulated by the addition of calcium. However, some works show that the half-lives of Cxs present in junctions can last 1-3 hours (Traub et al. 1989, Laird et al. 1991). It is possible that the reduced transit of Cxs to the cell membranes can cause Cxs with prolonged half-lives to build up in the cytoplasm. This excess of unused Cxs with prolonged half-lives might explain why the general quantity of protein does not change, even with a reduction of the mRNA available for protein synthesis. This hypothesis is supported by the observation described in other models, whose cells keep a cytoplasm population of Cxs on standby in their cytoplasm (Laird et al. 1995, Hernandez-Blazquez et al. 2001, Yano et al. 2001). Interestingly, two bands of $\mathrm{Cx}$ protein may be observed in the western-blot membrane, around the $32 \mathrm{kDa}$ region, suggesting that the heavier top band is the phosphorilated form of $\mathrm{C} \times 32$ and the lower band is the non-phosphorilated form and they coexist both in the fibrosis or normal state of the liver. Due to the importance of $\mathrm{C} \times 32$ for forming gap junctions in hepatic cells, we may assume that there was a decline in cellular communication processes, since the presence of these Cxs decreased in cellular membranes and increased in cytoplasm. In view of the fact that the gene of $\mathrm{C} \times 32$ is considered to be a tumor suppressor gene for liver tumors (Neveul et al. 1994), the reduction of its expression in fibrosis can favor the development of cells initiated in the process of malignant transformation.
Acknowledgements.- Financial support by FAPESP (Fellowship 2002/ 11182-8) and CNPq (Grant 470717/03-3).

\section{REFERENCES}

Barnes J.M. \& Magee P.N. 1954. Some toxic properties of dimethylnitrosamine. Brit. J. Industry Med. 11(3):167-174.

Cheville N.F. 1999. Healing and chronic inflammation, p.135-154. In: Cheville N.F. (Ed.), Introduction to Veterinary Pathology. 2nd ed. lowa State University Press, Ames.

Crawford J.M. 2005. Liver and biliary tract, p.878-927. In: Kumar V., Abbas A.K., Fausto N., Robbins S.L. \& Cotran R.S. (Eds), Robbins and Cotran Pathologic Basis of Disease. $7^{\text {th }}$ ed. Elsevier Saunders, Philadelphia.

Friedman S.L. 1993. The cellular basis of hepatic fibrosis: Mechanisms and treatment strategies. New Engl. J. Med. 328(25):1828-1835.

Hernandez-Blazquez F.J., Joazeiro P.P., Omori Y. \& Yamasaki H. 2001. Control of intracellular movement of connexins by e-cadherin in murine skin papilloma cells. Exp. Cell Res. 270:235-247.

Johnson S.E. 2000. Diseases of the liver and pancreas, p.1298-1325. In: _ (Ed.), Textbook of Veterinary Internal Medicine. Vol.2. $5^{\text {th }}$ ed. W.B. Saunders, Philadelphia.

Laird D.W., Puranam K.L. \& Rever J.P. 1991. Turnover and phosphorylation dynamics of connexin 43 gap junction protein in cultured cardiac myocytes. Biochem. J. 273(pt.1):67-72.

Laird D.W., Castillo M. \& Kasprzak L. 1995. Gap junction turnover, intracellular trafficking and phosphorylation of connexin 43 in brefeldin a-treated rat mammary tumor cells. J. Cell Biol. 131(5):1193-1203.

Lee M-H., Yoon S. \& Moon J.-O. 2004. The flavonoid naringenin inhibits dimethylnitrosamine-induced liver damage in rats. Biol. Pharmaceut. Bull. 27(1):72-76.

Livak K.J. \& Schmittgen T.D. 2001. Analysis of relative gene expression data using real-time quantitative PCR and the 2-CT method. Methods 25:402-408.

Magee P.N. 1956. Toxic liver injury: The metabolism of dimethylnitrosamine. Biochem. J. 64(4):676-682.

Magee P.N. 1958. Toxic liver injury: Inhibition of protein synthesis in rat liver by dimethylnitrosamine in vivo. Biochem. J. 70(4):606-611.

Moennikes O., Buchmann A., Ott T., Willecke L. \& Schwarz M. 1999. The effect of connexin 32 null mutation on hepatocarcinogenesis in different mouse strains. Carcinogenesis 20:1379-1382.

Nakata Y., Iwai M., Kimura S. \& T. Shimazu T. 1996. Prolonged decrease in hepatic connexin 32 in chronic liver injury induced by carbon tetrachloride in rats. J. Hepatology 25(4):529-537.

Neveul M.J., Hully J.R., Babcock K.L., Hertzberg E.L., Nicholson B.J., Paul D.L. \& Pitot H.C. 1994. Multiple mechanisms are responsible for altered expression of gap junction genes during oncogenesis in rat liver. J. Cell Sci. 107:83-95.

Paradis V., Dargere D., Vidaud M., De Gouville A.C., Huet S., Martinez V., Gauthier J.M., Ba N., Sobesky R., Ratziu V. \& Bedossa P. 1999. Expression of connective tissue growth factor in experimental rat and human liver fibrosis. J. Hepatology 30(4):968-976.

Pines M., Knopov V., Genina O., Lavelin I. \& Nagler A. 1997. Halofuginone, a specific inhibitor of collagen type I synthesis, prevents dimethylnitrosamine-induced liver cirrhosis. J. Hepatology 27:391-398.

Saez J.C., Connor J.A., Spray D.C. \& Bennet M.V.L. 1989. Hepatocyte gap junctions are permeable to the second messenger, inositol 1,4,5triphosphate and calcium ions. Proc. Natl Acad. Sci. USA 86:27082712.

Temme A., Buchmann A., Gabriel H.D., Nelles E., Schwarz M. \& Willecke K. 1997. High incidence of spontaneous and chemically induced liver tumors in mice deficient for connexin 32. Current Biology 7:713-716.

Traub O., Look J., Dermietzel R., Brummer F., Huiser D. \& Willecke K. 1989. Comparative characterization of the $21-\mathrm{kD}$ and $26-\mathrm{kD}$ gap 
junction proteins in murine liver and culture hepatocytes. J. Cell Biol. 108(3):1039-1051.

Watson P.J. 2004. Chronic hepatitis in dogs: A review of current understanding of the aetiology, progression, and treatment. Vet. J. 167:228-241.

Yamaoka K. 1995. Expression of gap junction protein connexin 32 and E-cadherin in human hepatocellular carcinoma. J. Hepatology. 22(5):536-539.

Yamasaki H. 1991. Aberrant expression and function of gap junctions during carcinogenesis. Environ. Hlth Perspectives 93:191-197.
Yano T., Hernandez-Blazquez F.J., Omori Y. \& Yamasaki H. 2001. Reduction of malignant phenotype of HPG2 cell is associated with the expression of connexin 26 but not connexin 32. Carcinogenesis 22(10):1593-1600.

Yasuda M., Shimizu I., Shiba M. \& Ito S. 1999. Suppressive effects of estradiol on dimethylnitrosamine-induced fibrosis of the liver in rats. J. Hepatology 29(3):719-727.

Zhang J.T. \& Nicholson B.J. 1989. Sequence and tissue distribution of a second protein of hepatic gap junctions, Cx26, as deduced from rats cDNA. J. Cell Biol. 109:3391-3401. 